\title{
POLITIK HUKUM PEMEKARAN DAERAH DALAM NEGARA KESATUAN REPUBLIK INDONESIA
}

\author{
Iskatrinah \\ Fakultas Hukum Wijayakusuma Purwokerto \\ Email: iskatrinahkatri@ymail.com
}

\begin{abstract}
Indonesia is a country which territory is divided into areas of the province, which is divided over the district and the city. Formation of the provinces, counties, and cities are set by law, may be merging some areas or parts of areas that side by side or division of a region into two regions or more, which is basically intended to improve public services in order to accelerate the realization of public welfare, in addition to as a means of political education at the local level. Forming regions should consider of various factors such as economic capacity, potential of the region, area, population, and consideration of the social aspects of political, social, cultural, defense and security as well as consideration and other terms that allow the region can organize and realize the purpose of establishing the area and the granting of regional autonomy.
\end{abstract}

\section{Kata Kunci: Negara Kesatuan, Pemekaran Daerah, Politik Hukum.}

\section{A. Latar Belakang}

Indonesia adalah negara yang bersifat majemuk (plural) dalam hal etnis, bahasa daerah, agama, budaya, geografi, demografi dan lain-lain. Keadaan geografis Indonesia yang berupa kepulauan berpengaruh terhadap mekanisme pemerintahan Negara Indonesia. Keadaan geografis yang berupa kepulauan ini menyebabkan pemerintah sulit mengkoordinasi pemerintahan yang ada di daerah. Untuk memudahkan pengaturan atau penataan pemerintahan, diperlukan adanya suatu sistem pemerintahan yang dapat berjalan secara efisien dan mandiri, serta dekat dengan rakyat sehingga saat ini telah terjadi pemekaran-pemekaran wilayah baru menjadi provinsi maupun kabupaten/kota.

Indonesia juga merupakan negara yang wilayahnya terbagi atas daerahdaerah provinsi. Daerah provinsi itu dibagi lagi atas daerah kabupaten dan daerah kota. Setiap daerah provinsi, daerah kabupaten, dan daerah kota mempunyai pemerintahan daerah yang diatur dengan undang-undang. Pemerintahan daerah 
adalah penyelenggaraan urusan pemerintahan oleh Pemerintah Daerah dan DPRD menurut asas otonomi dan tugas pembantuan dengan prinsip otonomi seluasluasnya dalam sistem dan prinsip Negara Kesatuan Republik Indonesia (NKRI) sebagaimana dimaksud dalam UUD 1945. Negara mengakui dan menghormati satuan-satuan pemerintahan daerah yang bersifat khusus atau bersifat istimewa yang diatur dengan undang-undang. Negara mengakui dan menghormati kesatuankesatuan masyarakat hukum adat serta hak-hak tradisonalnya sepanjang masih hidup dan sesuai dengan perkembangan masyarakat dan prinsip (NKRI), yang diatur dalam undang-undang.

Pembentukan daerah provinsi, daerah kabupaten, dan daerah kota ditetapkan dengan undang-undang. Pembentukan daerah dapat berupa penggabungan beberapa daerah atau bagian daerah yang bersandingan atau pemekaran dari 1 (satu) daerah menjadi 2 (dua) daerah atau lebih. Daerah dapat dihapus dan digabung dengan daerah lain apabila daerah yang bersangkutan tidak mampu menyelenggarakan otonomi daerah. Penghapusan dan penggabungan daerah beserta akibatnya ditetapkan dengan undang-undang. Untuk menyelenggarakan fungsi pemerintahan tertentu yang bersifat khusus bagi kepentingan nasional, pemerintah dapat menetapkan kawasan khusus dalam wilayah provinsi dan/atau kabupaten/kota.

Pembentukan daerah adalah pemberian status pada wilayah tertentu sebagai daerah otonom yang merupakan satu kesatuan masyarakat hukum yang mempunyai batas-batas wilayah yang berwenang mengatur dan mengurus sendiri urusan pemerintahan dan kepentingan masyarakat setempat menurut prakarsa sendiri berdasarkan aspirasi masyarakat dalam kerangka NKRI.

Konsekuensi diterapkannya undang-undang otonomi daerah tersebut melahirkan kompleksitas persoalan yang luar biasa di sejumlah daerah. Hal tersebut dapat di lihat dari munculnya berbagai dinamika politik lokal yang terjadi di berbagai daerah. Salah satu persoalan yang muncul adalah maraknya wacana pemekaran daerah yang terjadi baik di tingkatan provinsi maupun di tingkatan kabupaten/kota. 
Pembentukan, penggabungan dan penghapusan daerah pada hakikatnya bertujuan untuk meningkatkan pelayanan publik agar lebih optimal, memperpendek rentang kendali, dan mempercepat kesejahteraan masyarakat dalam memperkokoh keutuhan NKRI. Di sisi lain, banyak pula argumen yang diajukan untuk mendukung pemekaran, yaitu memberi kesempatan pada daerah untuk melakukan pemerataan pembangunan. Alasan lainnya adalah diupayakannya pengembangan demokrasi lokal melalui pembagian kekuasaan pada tingkat yang lebih kecil.

Fenomena keinginan berpisahnya satu daerah untuk membentuk daerah otonomi sendiri melalui mekanisme pemekaran wilayah yang sudah di rencanakan secara top down, maupun melalui usulan warganya (bottom up) saat ini menunjukkan keinginan masyarakat wilayah tersebut untuk memperoleh keuntungan yang lebih besar dari proses pembangunan selain kendala-kendala yang tejadi secara administrasi karena jauhnya letak geografis wilayah tersebut dari pusat kekuasaan provinsi/kabupaten, kurangnya pelayanan publik. J. Kaloh (2007: 194) mengatakan:

"Dalam konteks pemekaran daerah/wilayah tersebut yang lebih dikenal dengan pembentukan daerah otonom baru, bahwa daerah otonom tersebut diharapkan mampu memanfaatkan peluang yang lebih besar dalam mengurus dirinya sendiri, terutama berkaitan dengan pengelolaan sumbersumber pendapatan asli daerah, sumber daya alam, dalam rangka meningkatkan kesejahteraan dan pelayanan kepada masyarakat setempat yang lebih baik. Diharapkan mampu memanfaatkan peluang yang lebih besar dalam mengurus dirinya sendiri, terutama berkaitan dengan pengelolaan sumber-sumber pendapatan asli daerah, sumber daya alam, dalam rangka meningkatkan kesejahteraan dan pelayanan kepada masyarakat setempat yang lebih baik."

Pembentukan daerah pada dasarnya dimaksudkan untuk meningkatkan pelayanan publik guna mempercepat terwujudnya kesejahteraan masyarakat di samping sebagai sarana pendidikan politik local (H.A.W. Widjaja 2005: 134-135). Setidaknya ada 3 (tiga) pintu usulan pemekaran, yaitu melalui Kemendagri (jalur normatif), DPR dan DPD. Jalur normatif yang dimaksud memuat ketentuan dan persyaratan yang harus dilengkapi oleh setiap daerah yang menghendaki pembentukan daerah otonom baru yang terdiri dari 3 (tiga) persyaratan, yaitu 
administratif, teknis, dan fisik kewilayahan seperti yang tercantum dalam Peraturan Pemerintah Nomor 78 Tahun 2007.

Alasan paling mengemuka dalam wacana pemekaran daerah adalah sejalan dengan semangat otonomi daerah; beberapa provinsi/kabupaten/kota dianggap memiliki wilayah terlalu luas sehingga diperlukan upaya untuk memudahkan pelayanan administrasi dan pemangkasan birokrasi dari ibu kota provinsi ke daerah dengan cara pemekaran, yaitu dengan penyatuan beberapa kabupaten/kota menjadi provinsi baru, maupun penyatuan beberapa kecamatan/kelurahan menjadi kabupaten/kota baru.

Secara yuridis formal, Undang-undang No. 32 Tahun 2004 (sebelumnya UU No. 22 Tahun 1999) dan PP No. 78 Tahun 2007 tentang Tata Cara Pembentukan, Penghapusan, dan Penggabungan Daerah (sebelumnya PP No. 129 Tahun 2000 tentang Persyaratan, Pembentukan dan Kriteria Pemekaran, Penghapusan dan Penggabungan Daerah), pemekaran wilayah administratif menjadi kecenderungan baru dalam struktur pemerintahan di Indonesia, hingga diubah kembali dengan UU No. 23 Tahun 2014 tentang Pemerintahan Daerah.

Undang-undang Nomor 32 tahun 2004 tentang Pemerintahan Daerah, yang telah diubah dengan Undang-undang Nomor 23 Tahun 2014 dan PP Nomor 78 Tahun 2007 secara administratif mensyaratkan 5 kecamatan untuk membentuk kabupaten baru, untuk membentuk kota pemekaran minimal terdiri dari 4 kecamatan dan provinsi baru dapat dibentuk minimal terdiri dari 5 kabupaten/ kota. Selain itu, PP No. 78/2007 mensyaratkan adanya batas usia minimal. Pemekaran dapat dilakukan setelah mencapai batas minimal usia penyelenggaraan pemerintahan 7 tahun untuk kabupaten/kota, dan 10 tahun untuk provinsi (Pasal 8 PP No.78 Tahun 2007). Desentralisasi merupakan salah satu perubahan sosial politik yang dialami Indonesia dan diimplementasikan melalui Undang-undang 32 Tahun 2004 tentang Pemerintahan Daerah yang masih belum dikeluarkan PP yang baru walaupun undang-undang Pemerintahan Daerah telah diubah kembali dengan Undang-undang Nomor 23 Tahun 2014, khususnya yang menyangkut pembentukan dan kriteria pemekaran, penghapusan dan penggabungan daerah. 
Semangat otonomi daerah tercermin antara lain pada keinginan sebagian daerah untuk memekarkan diri dengan tujuan meningkatkan kesejahteraan masyarakat.

Keadaan tersebut telah menimbulkan sikap pro dan kontra di berbagai kalangan politisi, tokoh masyarakat, pejabat pemerintah, dan di antara para pakar. Hal yang diperdebatkan terkait dengan manfaat ataupun kerugian yang timbul dari banyaknya wilayah yang dimekarkan. Berbagai pandangan dan opini disampaikan untuk mendukung sikap masing-masing pihak. Fitrani (www.stialanbandung.ac. id), menyatakan bahwa pemekaran telah membuka peluang bagi terjadinya bureaucratic and political rent-seeking, yakni kesempatan untuk memperoleh keuntungan dana, baik dari pemerintah pusat maupun dari penerimaan daerah sendiri. Lebih lanjut dikatakan bahwa, karena adanya tuntutan untuk menunjukkan kemampuan menggali potensi wilayah, maka banyak daerah menetapkan berbagai pungutan untuk meningkatkan Pendapatan Asli Daerah (PAD). Hal ini menyebabkan terjadinya suatu perekonomian daerah berbiaya tinggi. Lebih jauh lagi timbul pula tuduhan bahwa pemekaran wilayah merupakan bisnis kelompok elit di daerah yang sekedar menginginkan jabatan dan posisi. Euforia demokrasi dan partai-partai politik yang memang terus tumbuh, dimanfaatkan kelompok elit ini untuk menyuarakan "aspirasinya" mendorong terjadinya pemekaran.

Kelahiran daerah atau wilayah baru ternyata memunculkan pula persoalanpersoalan baru terutama yang menyangkut dimensi sosial budaya berupa perasaan atau efek psikologis sosial bagi komunitas atau kelompok masyarakat tertentu di daerah menjadi termarjinalisasi dalam peranan, fungsi, dan kedudukannya dalam turut serta mewarnai dinamika sosial budaya di daerah tersebut, selain dampak politik, ekonomi, kewilayahan, pertahanan, keamanan, dan sebagainya.

\section{B. Metode Penelitian}

Jenis penelitian hukum dapat dibedakan menjadi penelitian hukum normatif dan penelitian hukum empiris/sosiologis. Penelitian hukum normatif merupakan penelitian yang datanya bersumber pada data sekunder dan berhubung data penelitian ini adalah data sekunder, maka termasuk dalam jenis penelitian hukum normatif. Sifat penelitian ini adalah deskriptif, yang bertujuan untuk 
memberikan gambaran tentang gejala-gejala sosial yang terkait dengan masalah politik hukum pemekaran daerah. Sumber data penelitian berupa bahan hukum primer, bahan hukum sekunder dan bahan hukum tersier. Metode pengumpulan data dilakukan menggunakan teknik studi dokumen, yang dianalisis dengan menggunakan teknik analisis kualitatif.

\section{Hasil Penelitian dan Analisis}

\section{Konsep negara kesatuan}

Konsep negara kesatuan adalah konsep bentuk negara paling tua dalam sejarah kenegaraan, karena sampai dengan abad pertengahan hanya dikenal bentuk negara kesatuan sebagai satu-satunya bentuk negara, adapun federasi sebagai padanan bentuk negara baru ada dan baru dikenal sejak lahirnya Amerika serikat sebagai satu negara merdeka (Hendarmin Ranadireksa 2007: 58-59).

Bentuk negara kesatuan (eenheidsstaat) adalah bentuk suatu negara yang merdeka dan berdaulat, yang di dalam seluruh wilayah negaranya hanya ada satu pemerintahan yang berkuasa (pusat). Negara kesatuan merupakan kebulatan tunggal dan yang berpusat satu (monosentris). Menurut Fred Isjwara (1974: 179) bahwa negara kesatuan adalah bentuk kenegaraan yang paling kokoh jika dibandingkan dengan federal atau konfederasi. Dalam negara kesatuan terdapat, baik persatuan (union) maupun kesatuan (unity). Dilihat dari segi susunan negara kesatuan, maka negara kesatuan bukan negara tersusun dari beberapa negara melainkan negara tunggal.

Abu Daud Busroh (1990: 53) mengutarakan bahwa: negara kesatuan adalah negara yang tidak tersusun daripada beberapa negara, seperti halnya dalam negara federasi, melainkan negara itu sifatnya tunggal, artinya hanya ada satu negara, tidak ada negara di dalam negara, sehingga dalam negara kesatuan itu juga hanya ada satu pemerintahan, yaitu pemerintahan pusat yang mempunyai kekuasaan atau wewenang tertinggi dalam segala lapangan pemerintahan. Pemerintahan pusat inilah yang pada tingkat terakhir dan tertinggi dapat memutuskan segala sesuatu dalamnegara tersebut. 
Negara kesatuan dapat dibedakan dalam 2 (dua) bentuk, yakni negara kesatuan dengan sistem sentralisasi dan negara kesatuan dengan sistem desentralisasi. Dalam negara kesatuan dengan sistem sentralisasi, segala sesuatu dalam negara langsung diatur dan diurus oleh pemerintah pusat dan daerah-daerah hanya tinggal melaksanakan segala apa yang telah diinstruksikan oleh Pemerintah Pusat, sedangkan dalam negara kesatuan dengan sistem desentralisasi, kepada daerah-daerah diberikan kesempatan dan kekuasaan untuk mengatur dan mengurus rumah tangganya sendiri (otonomi daerah) yang dinamakan dengan daerah otonom. Negara kesatuan sebagai negara dengan sentralisasi kekuasaan.

Menurut Thorsten V. Kalijarvi (Fred Isjwara 1974: 179), menyebutkan bahwa: negara-negara di mana seluruh kekuasaan dipusatkan pada satu atau beberapa organ pusat, tanpa pembagian kekuasaan antara Pemerintah Pusat dengan pemerintah bagian-bagian negara itu. Pemerintah bagian-bagian negara itu hanyalah bagian pemerintahan pusat yang bertindak sebagai wakil-wakil Pemerintah Pusat untuk menyelenggarakan administrasi setempat. Dalam negara kesatuan, bagian-bagian negara itu lazim disebut dengan daerah, sedangkan istilah “daerah" ini merupakan istilah teknis bagi penyebutan suatu bagian teritorial yang berpemerintahan sendiri dalam rangka negara kesatuan yang dimaksud. Kata Daerah (gebiedsdeel) dimaksudkan sebagai lingkungan yang dijelmakan dengan membagi satu kesatuan lingkungan yang disebut "wilayah" (gebied). Dengan kata lain bahwa istilah "daerah" bermakna "bagian" atau unsur dari suatu lingkungan yang lebih besar sebagai suatu kesatuan.

Menurut Sri Soemantri (1981: 87), menyebutkan bahwa adanya pelimpahan wewenang dari Pemerintah Pusat kepada daerah-daerah otonom bukanlah hal itu ditetapkan dalam konstitusinya, akan tetapi karena masalah itu adalah merupakan hakikat daripada negara kesatuan. C.F. Strong (1996: 52) mengemukakan bahwa ada 2 (dua) ciri mutlak yang melekat pada negara kesatuan, yaitu the supremacy of the centra parliament (adanya supremasi dari dewan perwakilan rakyat pusat) dan the absence of subsidiary sovereign bodies (tidak adanya badan-badan lainnya yang berdaulat). 
Utrecht mengemukakan bahwa dalam permulaan perkembangan kenegaraan, perlu adanya sentralisasi kekuasaan supaya kekuatan-kekuatan yang bertujuan akan meruntuhkan kesatuan yang baru itu dapat dilenyapkan. Apabila ternyata kekuatan-kekuatan itu sudah tidak ada lagi, hidup negara yang baru itu tidak terancam lagi oleh kekuatan-kekuatan yang bertujuan meruntuhkan kekuasaan, maka sentralisasi dapat dijadikan desentralisasi, bahkan lebih jauh lagi suatu desentralisasi yang bersifat federasi (Miriam Budiardjo 2004: 144).

Menurut Van Der Pot dalam H. Hutabarat (1996: 118) menyebutkan bahwa setiap negara kesatuan (unitary state) dapat disusun dan sentralisasi menurut asas dan sistem sentralisasi atau desentralisasi. Suatu pemerintahan sentralisasi dapat sepenuhnya dilaksanakan oleh dan dari pusat pemerintahan (single centralized government) atau oleh pusat bersama-sama organnya yang dipencarkan di daerah-daerah. Sentralisasi yang disertai pemencaran organ-organ yang menjalankan sebagian wewenang pemerintahan pusat di daerah dikenal sebagai desentralisasi. Desentralisasi akan didapat apabila kewenangan mengatur dan mengurus penyelenggaraan pemerintahan tidak semata-mata dilakukan oleh Pemerintah Pusat (central government), melainkan oleh satuan-satuan tingkat pemerintahan lebih rendah yang mandiri bersifat otonom (teritorial ataupun fungsional).

Negara kesatuan terpola dalam dalam dua struktur utama, yaitu pemerintah pusat dan pemerintah daerah (provinsi, kabupaten dan kota). Kajian pemerintahan negara kesatuan terdapat dua sendi utama, yaitu sistem pemerintahan yang bersifat sentralistik atau pemerintahan yang sifatnya desentralistik. Negara kesatuan disebut juga negara "unitaris", di dalam negara kesatuan hanya ada satu pemerintahan, yaitu pemerintah pusat yang mempunyai kekuasaan atau wewenang tertinggi dalam segala lapangan pemerintahan, Pemerintah Pusat inilah yang pada tingkat terakhir dan tertinggi dapat memutuskan segala sesuatu di dalam negara tersebut. Negara kesatuan dapat dibedakan dalam dua bentuk (Ni'matu Huda 2009: 28), yaitu: 
a. Negara kesatuan dengan sistem sentralisir, yang segala sesuatu dalam negara itu langsung diatur dan diurus oleh pemerintah pusat dan daerah-daerah tinggal melaksanakannya disebut negara kesatuan yang sentralisir.

b. Negara kesatuan dengan sistem desentralisasi, yang pembagian daerah yang pada tiap-tiap daerah tersebut mempunyai pemerintahan sendiri, yang disebut pemerintah daerah yang berhak mengatur dan mengurus rumah tangganya sendiri, yang dinamakan daerah otonom, tetapi pemerintah daerah tidak mempunyai kekuasaan atau wewenang yang tertinggi mengenai apapun dalam lapangan pemerintahan.

Terlepas dari dua sistem negara kesatuan di atas, negara kesatuan pada hakikatnya tidak terbagi, atau dalam arti lain kekuasaan pemerintahan pusat tidak dibatasi, karena konstitusi negara kesatuan tidak mengakui badan legislatif lain selain badan legislatif pusat. Kalaupun ada kewenangan bagi daerah, seperti membuat peraturan daerah (Perda), tidak berarti bahwa pemerintah daerah itu berdaulat, sebab pengawasan dan kekuasaan tertinggi tetap pada pemerintah pusat (Miriam Budiarjo 2004: 140).

Negara Indonesia, telah mengukuhkan keberadaan dirinya sebagai Negara Kesatuan yang berbentuk Republik sebagaimana disebutkan pada Pasal 1 angka (1) UUD 1945. Negara Kesatuan Republik Indonesia merupakan prinsip dasar dalam penyelenggaraan pemerintahan daerah dimana pada konsepsi tersebut di satu sisi mengukuhkan keberadaan daerah sebagai bagian nasional, tetapi di sisi lain memberikan stimulan bagi masyarakat daerah untuk mengartikulasi semua kepentingannya, termasuk masalah otonomi daerah dalam sistem hukum dan kebijakan nasional.

Idealnya tidak ada dan tidak mungkin terjadi suatu kebijakan nasional yang akan mengesampingkan, mengurangi atau bahkan menghilangkan otonomi daerah. Hai ini disebabkan oleh adanya pemberian otonomi daerah yang telah menjadi bagian yang tidak terpiahkan dari kebijakan nasional. Sebaliknya daerah juga tidak dapat menafikkan jati dirinya sebagai bagian dari negara kesatuan Republik Indonesia sehingga semua perilaku, kebijakan dan tindakan daerah tidak dapat bertentangan dengan kebijakan pusat. 
Penegasan sebagai negara kesatuan, tanggung jawab pelaksanaan tugastugas pemerintahan pada dasarnya tetap berada di tangan pemerintah pusat. Akan tetapi karena sistem pemerintahan Indonesia salah satunya menganut asas negara kesatuan yang didesentralisasikan, maka ada tugas-tugas tertentu yang diurus sendiri, sehingga menimbulkan hubungan timbal balik yang melahirkan adanya hubungan kewenangan dan pengawasan.

Berdasarkan konteks bentuk negara, meskipun bangsa Indonesia memilih bentuk negara kesatuan, tetapi di dalamnya terselenggara suatu mekanisme yang memungkinkan tumbuh dan berkembangnya keragaman antar daerah di seluruh tanah air. Kekayaan alam dan budaya antar daerah tidak boleh diseragamkan dalam struktur Negara Kesatuan Republik Indonesia, dengan kata lain, diselenggarakan dengan jaminan otonomi yang seluas-luasnya kepada daerah-daerah untuk berkembang sesuai dengan potensi dan kekayaan yang dimilikinya masingmasing, tentunya dengan dorongan, dukungan, dan bantuan yang diberikan oleh pemerintah pusat.

Pemahaman yang ideal terhadap penerapan desentralisasi dan otonomi daerah dapat menjadi landasan dalam menghadapi gejala euforia yang begitu deras di daerah, pemerintah mempunyai konsep yang tepat dalam memandu pelaksanaan otonomi daerah ini. Pemerintah selalu mengamati aspirasi dan kebijakan yang berkembang di daerah agar tidak mengarah pada tuntutan yang destruktif dan menggoyahkan konsepsi negara kesatuan. Aspirasi dan kebijakan daerah harus dipandu ke arah aspirasi yang positif guna memberdayakan daerah itu sendiri. Prinsip integrasi bangsa dalam UUD 1945 harus tetap dipegang teguh, dijadikan acuan dalam setiap pengambilan kebijakan, baik pada Pemerintah Pusat maupun Pemerintah Daerah.

\section{Impelementasi desentralisasi dalam bingkai negara kesatuan}

Desentralisasi merupakan pelaksanaan dari konsep adanya pemerintahan yang bersifat otonom yaitu kesatuan masyarakat hukum yang mempunyai batas wilayah tertentu yang bertugas dan berkewajiban serta berwenang menyelenggarakan urusan rumah tangganya sendiri. Berdasarkan alasan ini, maka ada penyerahan urusan pemerintahan yang diserahkan dari pemerintah pusat kepada 
pemerintah daerah, untuk selanjutnya menjadi urusan rumah tangganya sendiri (Ateng Safrudin 1985: 33).

Pasal 1 ayat (7) Undang-undang Nomor 32 Tahun 2004 menyebutkan defenisi desentralisasi adalah penyerahan wewenang pemerintahan oleh pemerintah kepada daerah otonom untuk mengatur dan mengurus urusan pemerintahan dalam sistem Negara Kesatuan Republik Indonesia. Ditinjau dari Hukum Tata Negara (HTN), desentralisasi memunculkan satuan organisasi kenegaraan tingkat rendah yaitu institusi Daerah Otonom.

Berdasarkan Pasal 1 ayat (6) maka yang dimaksud Daerah Otonom yang selanjutnya disebut Daerah adalah kesatuan masyarakat hukum yang mempunyai batas-batas wilayah yang berwenang mengatur dan mengurus urusan pemerintahan dan kepentingan masyarakat setempat menurut prakarsa sendiri berdasarkan aspirasi masyarakat dalam sistem Negara Kesatuan Republik Indonesia. Hal ini menunjukkan bahwa dari aspek HTN, Daerah Otonom termasuk (staatrechtelijk), yan lahir dari prinsip pemencaran kekuasaan (spreiding van machten). Menurut Bagir Manan (1994: 247), pemencaran kekuasaan menurut desentralisasi adalah pemencaran kekuasaan dalam rangka susunan dan organisasi negara bukan dalam susunan atau organisasi pemerintahan. Karena bersangkutan dengan organisasi negara, pemencaran kekuasaan menurut desentralisasi bersifat ketatanegaraan atau dalam lapangan tata negara.

Otonomi adalah sistem dari negara kesatuan (unitary state, een heidstaat). Otonomi adalah fenomena dari negara kesatuan (Bagir Manan 1992: 2). Meskipun otonomi bersifat staatrechtelijk, tetapi isi rumah tangga daerah otonom hanya mengenai fungsi pemerintahan atau fungsi administrasi negara. Kalaupun ada fungsi legislasi, hanya terbatas pada pengaturan di bidang administrasi negara (administratieregelen) (Bagir Manan 2000: 32). Artinya, dari aspek isi rumah tangga daerah, otonomi daerah merupakan kajian Hukum Administrasi Negara, otonomi mengadung aspek pemencaran wewenang pemerintahan.

Untuk menganalisa lebih jauh tentang fenomena yang sekarang banyak terjadi yang berkaitan dengan keinginan untuk pembentukan daerah, atau bahkan penghapusan daerah propinsi/kabupaten/kota, perlu kiranya konsep desentralisasi 
untuk dikaji secara tersendiri dengan mempertimbangan konsep desentralisasi yang dikemukan oleh para ahli.

Alasan-alasan mengapa desentralisasi dianut, menurut The Aliang Gie (1968: 35-41), adalah:

a. Dilihat dari sudut politik sebagai permainan kekuasaan, desentralisasi dimaksudkan untuk mencegah penumpukan kekuasaa pada satu pihak saja yang pada akhirnya dapat menimbulkan tirani.

b. Dalam bidang politik, penyelenggaraan desentralisasi dianggap sebagai tindakan pendemokrasian, untuk menarik rakyat ikut serta dalam pemerintahan dan melatih diri dlam mempergunakan hak-hak demokrasi.

c. Dari sudut teknis organisatoris pemerintahan, alasan mengadakan pemerintahan daerah (desentralisasi) adalah semata-mata untuk mencapai suatu pemerintahan yang efisien. Apa yang dianggap lebih untuk diurus oleh Pemerintah setempat pengurusannya diserahkan kepada Daerah. Hal-hal yang lebih tepat di Tangan Pusat tetap diurus oleh Pemerintah Pusat.

d. Dari sudut kultural, desentralisasi perlu diadakan supaya perhatian dapat sepenuhnya ditumpahkan kepada kekhususan sesuatu Daerah, seperti geografi, keadaan penduduk, kegiatan ekonomi, watak kebudayaan, atau latar belakang sejarahnya.

e. Dari sudut kepentingan pembangunan ekonomi, desentralisasi diperlukan karena Pemerintah daerah dapat lebih banyak dapat lebih banyak dan secara langsung membantu pembangunan tersebut.

Menurut Josef Riwu Kaho (1997: 12-13), keuntungan yang diperoleh dengan dianutnya sistem desentralisasi adalah sebagai berikut:

a. Mengurang bertumpuknya pekerjaan di pusat pemerintahan;

b. Dalam menghadapi masalah yang amat mendesak membutuhkan tindakan yang cepat, daerah tidak perlu menunggu instruksi lagi dari Pemerintah Pusat;

c. Dapat mengurangi birokrasi dalam arti yang buruk karena setiap keputusan dapat segera dilaksanakan;

d. Dalam sistem deentralisasi, dapat diadakan pembedaan (diferensiasi) dan pengkhususan (spesialisasi) yang berguna bagi kepentingan tertentu. Khusus- 
nya desentralisasi teritorial, dapat lebih mudah menyesuaikan diri kepada kebutuhan/keperluan dan keadaan khusus daerah;

e. Dengan adanya desentralisasi teritorial daerah otonom dapat merupakan semacam laboratorium dalam hal yang berhubungan dengan pemerintahan, yang dapat bermanfaat bagi seluruh negara. Hal-hal yang ternyata baik, dapat diterapkan di seluruh wilayah Negara, sedangkan yang kurang baik, dapat dibatasi pada suatu daerah tertentu saja dan oleh karena itu dapat lebih mudah untuk ditiadakan;

f. Mengurangi kemungkinan kesewenang-wenangan dari Pemerintah Pusat

g. Dari segi psikologis, desentralisasi dapat lebih memberikan kepuasan bagi daerah-daerah karena sifatnya yang lebih langsung.

Pembentukan daerah otonom sebagai perwujudan dari sistem desentralisasi pada akhirnya merupakan tuntutan hukum, tuntutan negara kesejahteraan, tuntutan demokrasi, dan tuntutan kebhinekaan, sebagaimana yang dikemukakan oleh Bagir Manan (1989: 1), yaitu:

a. Tuntutan hukum, Indonesia adalah negara berdasarkan atas hukum (rechtsstaat), sebab suatu ciri negara hukum adalah adanya pembagian kekuasaan dan pemencaran kekuasaan (scheidingen spreiding van machten). Pembagian damn pemencaran tersebut sebagai upaya mencegah bertumpuknya kekuasaan pada satu pusat pemerintahan yang akan memberikan beban pekerjaan yangharus dijalankan dengan pemencaran. Pusat akan diringankan dalam menjalankan pekerjaan. Tidak kalah pentingya pemencaran mempunyai fungsi check and balance;

b. Tuntutan negara kesejahteraan, negara sejahtera adalah negara hukum yang memperhatikan pada upaya mewujudkan kesejahteraan orang banyak. UUD 1945, baik dalam pembukaan maupun dalam batang tubuh, memuat berbagai ketentuan yang meletakan kewajiban pada negara atau pemerintah untuk mewujudkan kesejahteraan orang banyak. Bahkan sila kelima Pancasila dengan tegas menyatakan prinsip "keadilan sosial bagi seluruh rakyat Indonesia"; 
c. Tuntutan demokrasi, kerakyatan atau kedaulatan adalah demokrasi. Dalam batang tubuh UUD 1945 ditegaskan bahwa "kedaulatan ada ditangan rakyat". Kerakyatan atau demokrasi menghendaki partisipasi daerah otonom yang disertai badan perwakilan merupakan wadah (yang memperluas) kesempatan rakyat berpartisipasi;

d. Tuntutan kebhinekaan, rakyat (bangsa) Indonesia, baik sosial, ekonomi, maupun budaya adalah masyarakat pluralistik yang mempunyai sifat dan kebutuhan yang berbeda-beda. Untuk mewujudkan keadilan, kesejahteraan dan keamanan tidak mungkin"memaksa" keseragaman (uniformitas). Setiap keseragaman dapat meningkatkan gangguan terhadap rasa keadilan, kesejahteraan, dan keamanan. Daerah otonom merupakan sarana mewadahi perbedaan tersebut dengan prinsip Bhineka Tunggal Ika.

Perwujudan dari sistem desentralisasi dalam suatu pemerintahan tersebut adalah penyelenggaraan otonomi daerah pada daerah otonom (Ateng Sarifudin 1985: 23). Sistem desentralisasi di Indonesia menurut garis perkembangan sejarah tetap dipegang teguh oleh Negara Kesatuan Republik Indonesia, sekalipun dari satu periode ke periode lainnya terlihat adanya perbedaan dalam pelaksanaanya. Sistem desentralisasi tetap menjadi menjadi bagian dalam praktik pemerintahan negara sejak berlakunya Undang-Undang Dasar 1945, Konstitusi RIS, UndangUndang Dasar Sementara 1950, sampai sekarang yaitu Undang-Undang Dasar 1945 yang telah mengalami empat kali amandemen.

Langkah-langkah penting telah dilakukan oleh pemerintah untuk mewujudkan sistem desentralisasi, ini terlihat dari kelahiran peraturan perundangundangan yang mengatur tentang pemerintahan daerah. Penggantian peraturan perundang-undangan yang mengatur tentang pemerintahan daerah. Penggantian peraturan perundangan mengenai pemerintahan daerah yang telah dilakukan oleh Pemerintah semata-mata untuk mencari bentuk otonomi daerah yang sebenarnya, sebagai wujud penyelenggaraan pemerintahan penganut sistem desentralisasi.

Menurut Logemann, sebagaimana dikutip Ateng Syarifudin (1985: 24), bahwa kebebasan bergerak yang diberikan kepada daerah otonom berarti memberi kesempatan kepadanya untuk mempergunakan prakarsanya sendiri dari segala 
macam kekuasaannya, untuk mengurus kepentingan umum (penduduk) pemerintahan yang demikiaan itu dinamakan otonom, dan selain itu dikatakan bahwa istilah "otonomi" mempunyai makna kebebasan atas kemandirian (zelfstandigheid) tetapi bukan kemerdekaan (onafhankelijkheid). Kebebasan yang terbatas atau kemandirian itu adalah wujud pemberian kesempatan yang harus dipertanggungjawabkan.

Pada akhirnya penerapan konsep desentralisasi dengan pembentukan daerah otonom, dimaksudkan untuk memperlancar roda pemerintahan, demikian pula di Indonesia, mengingat wilayahnya yang luas, yang terdiri atas beribu-ribu pulau yang besar dan kecil, serta masyarakat yang pluralistik dari segi agama, budaya, ras atau suku serta aspek-aspek lainnya yang berbeda-beda bentuk dan coraknya, sehingga Pemerintah Pusat tidak mungkin dapat menyelenggarakan pemerintahan dengan baik, apabila segala sesuatunya dipusatkan dan dilaksanakan sendiri. Oleh karena itu kepada daerah-daerah diberikan wewenang mengatur dan mengurus rumah tangganya sendiri untuk meningkatkan daya guna penyelenggaraan pemerintah dalam rangka pelayanan kepada masyarakat dan pelaksanaan pembangunan (R. D. H. Koesoemahatmadja 1979: 11-12).

\section{Politik hukum pembentukan dan penghapusan daerah}

Pembentukan daerah pada dasarnya dimaksudkan untuk meningkatkan pelayanan publik guna mempercepat terwujudnya kesejahteraan masyarakat, disamping sebagai sarana pendidikan politik di tingkat lokal. Penjelasan UU No. 32 Tahun 2004 menegaskan pembentukan daerah harus mempertimbangkan berbagai faktor seperti kemampuan ekonomi, potensi daerah, luas wilayah, kependudukan, dan pertimbangan dari aspek sosial politik, sosial budaya, pertahanan keamanan serta pertimbangan dan syarat lain yang memungkinkan daerah itu dapat menyelenggarakan dan mewujudkan tujuan dibentuknya daerah dan diberikannya otonomi daerah.

Pada hakikatnya tujuan dari dibentuknya daerah otonomi baru adalah untuk mensejahterakan masyarakat. Adapun bagian dari pertimbangan pemekaran daerah yang dilakukan oleh pemerintah adalah sebagai berikut: 
a. mempercepat pembangunan;

b. memperlancar distribusi kesejahteraan;

c. pertimbangan strategis di wilayah perbatasan;

d. menyediakan pelayanan publik yang lebih baik;

e. memperlancar pertumbuhan ekonomi penduduk setempat;

f. peningkatan keamanan; dan

g. peningkatan hubungan yang serasi antara pusat dan daerah.

Berdasarkan hasil kajian, terdapat alasan-alasan yang mendasari dilaksanakannya pemekaran daerah adalah (Ahmad Satibi http://sunarti3383.blogspot. com/2013/04/pengembangan-wilayah-pada-daerah-daerah_23.html):

a. Alasan mendekatkan pelayanan kepada masyarakat. Hal ini dijadikan alasan utama karena adanya kendala geografis, infrastruktur dan sarana perhubungan yang minim.

b. Alasan historis, pemekaran suatu daerah dilakukan karena alasan sejarah, yaitu bahwa daerah hasil pemekaran memiliki nilai historis tertentu.

c. Alasan kultural atau budaya (etnis), dimana pemekaran daerah terjadi karena menganggap adanya perbedaan budaya antara daerah yang bersangkutan dengan daerah induknya.

d. Alasan ekonomi, dimana pemekaran daerah diharapkan dapat mempercepat pembangunan di daerah.

e. Alasan anggaran, pemekaran daerah dilakukan untuk mendapatkan anggaran dari pemerintah.

f. Alasan keadilan, bahwa pemekaran dijadikan alasan untuk mendapatkan keadilan. Artinya, pemekaran daerah diharapkan akan menciptakan keadilan dalam hal pengisian jabatan pubik dan pemerataan pembangunan.

Pemekaran daerah/wilayah yang lebih dikenal dengan pembentukan daerah otonom baru, bahwa daerah otonom tersebut diharapkan mampu memanfaatkan peluang yang besar dalam mengurus dirinya sendiri, terutama berkaitan dengan pengelolaan sumber-sumber pendapatan asli daerah, sumber daya alam, dan pengelolaan bantuan Pemerintah Pusat kepada Daerah Otonom dalam rangka meningkatkan kesejahteraan dan pelayanan masyarakat setempat yang lebih baik. 
Terdapat beberapa urgensi (hal yang sangat penting dan mendesak) dari pembentukan dan pemekaran wilayah, yaitu (J. Kaloh 2007: 195-196):

a. Meningkatnya pelayanan pemerintah kepada masyarakat, sehingga kehidupan masyarakat akan secara cepat terangkat dan terbebas dari kemiskinan dan keterbelakangan seiring meningkatnya kesejahteraan.

b. Memperpendek span of control (rentang kendali) manajemen pemerintahan dan pembangunan, sehingga fungsi manajemen pemerintahan akan lebih efektif, efisien, dan terkendali.

c. Untuk proses pemberdayaan masyarakat dengan menumbuhkembangkan inisiatif, kreatifitas, efisiensi, dan terkendali.

d. Menumbuhkan dan mengembangkan proses pembelajaran berdemokrasi masyarakat, dengan keterlibatan mereka dalam proses politik dan pembangunan.

e. Khusus daerah atau wilayah-wilayah perbatasan/kepulauan, pembentukan wilayah ini menjadi beberapa kawasan khusus merupakan sesuatu yang sangat urgen, karena hal tersebut:

1) membuka keterisolasian masyarakat akibat keterbelakangan dan kemiskinan daerah;

2) memberi akses bagi pertumbuhan dan perkembangan ekonomi, sosial, dan budaya masyarakat;

3) meningkatkan kesejahteraan hidup masyarakat kepulauan;

4) memajukan daerah kepulauan sejajar sebagai beranda terdepan NKRI; dan

5) memperkuat sistem pertahanan keamanan nasional serta tegaknya NKRI.

Dalam praktik dapat terjadi bahwa suatu daerah dihapus dan digabung dengan daerah lain apabila daerah yang bersangkutan tidak mampu menyelenggarakan otonomi daerah. Proses penghapusan dan penggabungan daerah otonom dilakukan setelah melalui proses evaluasi terhadap penyelenggaraan pemerintahan daerah. Evaluasi yang dimaksud adalah berupa penilaian dengan menggunakan pengukuran kinerja serta indikator-indikatornya, yang meliputi masukan, proses, keluaran, dan dampak. 
Aspek lain yang dievaluasi antara lain: keberhasilan dalam penyelenggaraan pemerintahan dan pembangunan; upaya-upaya kebijakan yang diambil; ketaatan terhadap peraturan perundang-undangan dan kebijakan nasional, dan dampak dari kebijakan daerah. Demi untuk menjaga dan rasa adil, penghapusan dan penggabungan daerah otonom beserta akibatnya ditetapkan dengan undangundang. Mengenai perubahan batas daerah, perubahan nama daerah, atau pemindahan ibukota yang tidak mengakibatkan penghapusan suatu daerah ditetapkan dengan Peraturan Pemerintah (B.N. Marbun 2010: 111).

Upaya memperkokoh konsolidasi demokrasi sebagai pilihan sistem pemerintahan, harus didasarkan pada prinsip "Bhinneka Tunggal Ika" (berbedabeda tetapi tetap satu), dan oleh sebab itu setiap dinamika lokal yang mengarah pada semangat penguatan neo-primordialisme, khususnya dalam etnoreligius yang dapat memecah belah bangsa, harus dikembalikan pada terjaganya negara-bangsa (nation state). Singkatnya, dalam menciptakan keamanan yang dinamis rujukan empat pilar: Pancasila, UUD 1945, NKRI dan Bhineka Tunggal Ika, merupakan harga mati yang harus menjadi rujukan utama dalam setiap pemekaran daerah baru.

Peranan hukum yang tegas dan konsisten sangat diperlukan seiring dengan munculnya tuntutan pemekaran daerah otonom yang cenderung subyektivitas dan irasional. Undang-undang Nomor 32 Tahun 2004 tentang Pemerintahan Daerah mengatur persyaratan dalam pembentukan daerahotonom yang pada dasarnya juga melandasi persyaratan pemekaran daerah. Persyaratan dalam pembentukan daerah otonom menurut Pasal 5 ayat (1) Undang-undang Nomor 32 Tahun 2004 meliputi syarat administratif, syarat teknis, dan syarat fisik kewilayahan, tetapi dengan berlakunya Undang-undang No. 23 Tahun 2014 tentang Pemerintahan Daerah sebagai pengganti Undang-undang No. 32 Tahun 2004, syarat dan mekanisme untuk pembentukan daerah otonom yang baru menjadi lebih terperinci dan lebih ketat.

Undang-undang No. 23 Tahun 2014 menegaskan syarat pembentukan daerah berubah menjadi syarat pembentukan daerah persiapan, yang diatur dalam Pasal 33 ayat (3), yang kini membagi persyaratan pembentukan daerah persiapan 
menjadi persyaratan dasar dan persyaratan administratif. Persyaratan dasar yang dimaksudkan dalam Pasal 33 ayat (3) tersebut meliputi persyaratan dasar kewilayahan dan persyaratan dasar kapasitas daerah.

Persyaratan administratif untuk daerah provinsi dan untuk daerah kabupaten memiliki susunan yang berbeda. Untuk daerah provinsi meliputi persetujuan bersama DPRD kabupaten/kota dengan bupati/wali kota yang akan menjadi cakupan wilayah daerah persiapan provinsi; dan persetujuan bersama DPRD provinsi induk dengan gubernur daerah provinsi induk. Sedangkan untuk daerah kabupaten/kota meliputi keputusan musyawarah desa yang akan menjadi cakupan wilayah daerah kabupaten/kota; persetujuan bersama DPRD kabupaten kota induk dengan bupati/wali kota daerah induk; dan persetujuan bersama DPRD provinsi dengan gubernur dari daerah provinsi yang mencakupi daerah persiapan kabupaten/kota yang akan dibentuk.

Berdasarkan Undang-undang No. 23 Tahun 2014 tentang Pemerintahan Daerah ini pemekaran daerah kini sudah tidak bisa dilakukan secara otomatis. Hal ini dikarenakan akan ada jeda waktu persiapan untuk daerah yang akan melakukan pemekaran sebelum daerah tersebut menjadi daerah otonomi baru (DOB). Persyaratan pemekaran daerah menjadi semakin ketat diakibatkan karena banyak fakta bahwa banyak daerah otonomi baru yang yang tidak layak dalam arti kinerja dan pemerintahan yang buruk.

Mekanisme pengetatan yang dimaksud adalah dimana daerah persiapan tersebut ditentukan dengan peraturan pemerintah, lalu daerah persiapan tersebut diberikan jangka waktu 3 (tiga) tahun untuk melakukan kegiatan administrasi yang dipimpin oleh kepala daerah persiapan, dan jika dalam jangka waktu 3 (tiga) tahun daerah persiapan dapat memenuhi syarat, maka barulah daerah persiapan dapat ditetapkan menjadi daerah otonomi baru. Sedangkan apabila dalam jangka waktu 3 (tiga) tahun daerah persiapan tidak dapat memenuhi persyaratan maka daerah persiapan tersebut tidak dapat melakukan pemekaran atau tidak dapat menjadi daerah otonom baru.

Menurut Djohermansyah Djohan dalam Haris Syamsudin (2005: 214), dikatakan bahwa maraknya pemekaran wilayah yang disebabkan oleh otonomi 
daerah ini telah menimbulkan beberapa faktor utama penyebab pemekaran daerah, yaitu kecendrungan untuk homogenitas, beberapa pemekaran daerah lebih didasari motif ingin lepas dari himpitan "penindasan" kelompok lain atas dasar etnis, agama, dan lainya. Persepsi jangka pendek elite daerah lebih mendominasi dalam pertimbangan menyusun usulan pemekaran daerah dibandingkan kajian yang dapat dipertanggungjawabkan yang mempertimbangkan secara matang implikasi pemekaran daerah.

Secara umum, penentuan pemekaran daerah sepantasnya didasarkan pada persyaratan yang terukur dengan tiga langkah tujuan preventif, yaitu pertama, pemekaran daerah dimaksudkan untuk menguatkan etika profesionalisme dalam pelayanan publik pemerintah daerah kepada masyarakat yang akan menciptakan hubungan yang bersifat kesetaraan antara birokrasi dan publik yang dilayani. Kedua, pemekaran daerah ditunjukan pada penerapan manajemen dan penguasaan teknologi yang dalam dari birokrasi pemerintahan daerah untuk melayani publik, sehingga pelayanan yang diberikan cenderung bersifat cepat, tepat, mudah, padat teknologi, dan padat informasi. Ketiga, pemekaran daerah dilandasi atas profesionalisme, karena rentang kendali yang lebih sempit sehingga pengawasan penyelenggaraan pemerintahan dapat terjamin kualitasnya (Hari Subarno 2008: 194).

\section{Simpulan dan Saran}

\section{Simpulan}

Kenyataan bahwa pemekaran wilayah dan pembentukan daerah baru tidak menjamin secara serta merta membuat perubahan yang diinginkan, yaitu kesejahteraan dan peningkatan pelayanan publik. Hal ini karena inisiatif pemekaran dan pembentukan daerah tidak merupakan bagian suara terbesar masyarakat yang bersangkutan melainkan merupakan inisiatif elit politik maupun birokrasi yang cenderung mengejar kekuasaan. Berdasarkan keadaan tersebut dapat dikatakan bahwa pemekaran wilayah dan pembentukan daerah baru tidak mencerminkan desentralisasi yang dilandasi filosofi Negara Kesatuan Republik Indonesia, karena justru pembentukan daerah otonom baru menimbulkan potensi 
konflik horisontal antar daerah, seperti mengenai tata batas wilayah, penolakan penggabungan.

\section{Saran}

Untuk mengatasi permasalahan tersebut, perlu dipertimbangkan bahwa untuk pemekaran wilayah dan pembentukan daerah baru, maka faktor utama yang harus dijadikan perhatikan adalah kesejahteraan dan peningkatan pelayanan publik yang memang benar-benar ditujukan bagi masyarakat. 


\section{DAFTAR PUSTAKA}

\section{Buku:}

Abu Daud Busroh. 1990. Ilmu Negara. Jakarta: Bumi Aksara.

Ateng Sarifudin. 1985. Pasang Surut Otonomi Daerah. Bandung: Bina Cipta

1985. Mempelajari Undang-undang tentang Pokok-pokok Pemerintahan di Daerah Tahun 1974 dalam Pemantapan Pelaksanaan Undang-undang Nomor 5 Tahun 1974 tentang Pokok-pokok Pemerintahan di Daerah. Jakarta: Sinar Baru.

Bagir Manan. 1989. Pemerintah Daerah (Bahan Penataran"Administrative Organization and Planing”), Kerjasama Indonesia-Belanda. Yogyakarta: Universitas Gadjah Mada.

--------. 1992. Perjalanan Historis Pasal 18 UUD 1945. Karawang: Unsika.

---------. 1994. Hubungan Hubungan Pusat dan Daerah Menurut UUD 1945. Jakarta: Pustaka Sinar Harapan.

Strong, C.F. 1996. Modern Political Constitusions: An Introductions to the Comparative Study of Their History and Existing. London: The English Book Society and Sidgwick \& Jackson Limited.

Fred Isjwara. 1974. Pengantar Ilmu Politik. Bandung: Binacipta.

Hari Subarno. 2008. Untaian Pemikiran Otonomi Daerah Memandu Otonomi Daerah Menjaga Kesatuan Bangsa. Jakarta: Sinar Grafika.

Haris Syamsudin. 2005. Desentralisasi dan Otonomi Daerah: Desentralisasi, Demokratisasi dan Akuntabilitas Pemerintahan Daerah. Jakarta: Yayasan Obor.

Hendarmin Ranadireksa. 2007. Visi Bernegara: Arsitektur Konstitusi Demokratik, Mengapa Ada Negara yang Gagal Melaksanakan Demokrasi. Bandung: Fokusmedia.

Hutabarat, Martin H. dkk. (Ed.) 1996. Hukum dan Politik Indonesia Tinjauan Analitis Dekrit Presiden dan Otonomi Daerah. Jakarta: Pustaka Sinar Harapan.

Josef Riwu Kaho. 1997. Prospek Otonomi Daerah di Negara Republik Indonesia, Identifikasi Beberapa Faktor yang Mempengaruhi Penyelenggaraannya. Jakarta: Rajawali Pers.

Kaloh, J. 2007. Mencari Bentuk Otonomi Daerah, Suatu Solusi dalam Menjawab Kebutuhan Lokal dan Tantangan Global. Edisi Revisi. Jakarta: Rineka Cipta. 
Koesoemahatmadja, R.D.H. 1979. Peranan Administrasi dalam Pembangunan. Jakarta: Eresco.

Marbun, B.N. 2010. Otonomi Daerah 1945-2010 Proses dan Realita. Edisi Revisi, Jakarta: Pustaka Sinar Harapan.

Miriam Budiardjo. 2004. Dasar-dasar Ilmu Politik. Jakarta: Gramedia Pustaka Utama.

Ni'matu Huda. 2009. Hukum Pemerintahan Daerah. Bandung: Nusa Media.

Sri Soemantri M. 1981. Pengantar Perbandingan Antar Hukum Tata Negara. Jakarta: Rajawali.

The Liang Gie. 1968. Pertumbuhan Pemerintahan Daerah di Negara Kesatuan Republik Indonesia. Jilid III. Jakarta: Gunung Agung.

Widjaja, H.A.W. 2005. Penyelenggaraan Otonomi di Indonesia. Jakarta: PT. Raja Grafindo Persada.

\section{Makalah:}

Bagir Manan. 2000. "Wewenang Propinsi, Kabupaten, dan Kota dalam Rangka Otonomi Daerah". Makalah. Disampaikan dalam Seminar Nasional. Bandung: Fakultas Hukum UNPAD.

\section{Peraturan Perundang-undangan:}

Republik Indonesia, Undang Undang Dasar Tahun 1945

Republik Indonesia, Undang-undang Nomor 23 Tahun 2014 tentang Pemerintahan Daerah

Republik Indonesia, Peraturan Pemerintah Nomor 78 Tahun 2007 tentang Tata Cara Pembentukan, Penghapusan, dan Penggabungan Daerah

\section{Internet:}

Ahmad Satibi. Pengembangan Wilayah pada Daerah-daerah Pemekaran, dalam http://sunarti3383.blogspot.com/2013/04/pengembangan-wilayah-padadaerah-daerah_23.html., diakses tanggal 13 Agustus 2016. 


\section{BIODATA PENULIS}

$\begin{array}{ll}\text { Nama } & \text { : Dr. Iskatrinah, S.H., M.H } \\ \text { Pekerjaan } & : \text { Dosen Fakultas Hukum Universitas Wijayakusuma Purwokerto } \\ \text { Jabatan } & : \text { Lektor Kepala } \\ \text { Nomor HP } & : 085291955818 \\ \text { E-mail } & : \text { iskatrinahkatri@ ymail.com } \\ \text { Alamat Kantor } & : \text { Jl. Kampus Karangsalam, Purwokerto, Jawa Tengah-53152. }\end{array}$ 